\title{
MELDONIUMAS KARDIOVASKULINIŲ IR NEUROLOGINIŲ LIGŲ BEI CUKRINIO DIABETO GYDYMUI
}

\author{
Šarūnė Maksvytytė ${ }^{1}$, Pranas Šerpytis ${ }^{1,2}$ \\ ${ }^{1}$ Vilniaus universiteto Medicinos fakultetas, ${ }^{2}$ Vilniaus universiteto ligonine Santaros klinikos
}

\begin{abstract}
Raktažodžiai: meldoniumas, veikimo mechanizmas, farmakologinès savybès, dopingas, kardioprotekcija, COVID-19, neuroprotekcija, cukrinis diabetas.
\end{abstract}

\section{Santrauka}

Meldoniumas (farmacinis vaisto pavadinimas - mildronatas) - tai veiklioji medžiaga, mažinanti L-karnitino koncentraciją kraujo plazmoje ir audiniuose, pasižyminti metabolizmą moduliuojančiu efektu. Dèl fizinị pajègumą didinančio poveikio šis vaistas pasaulinès dopingo agentūros ịrašytas ị draudžiamujų medžiagų sąrašą. Šiuo metu vienintelè Lietuvoje registruojama terapinè meldoniumo indikacija - papildomas lengvo lètinio širdies nepakankamumo gydymas. Meldoniumo farmakologinès savybès ir galimas potencialas gydant ịvairias ligas kol kas ištyrinètas nepakankamai, todèl pastaruoju metu dèl savo veikimo ypatumų šis vaistas kelia vis didesnį mokslininkų susidomèjimą. Šiame straipsnyje aptariamas meldoniumo veikimo mechanizmas, jo farmakologinès savybès, maistiniai šaltiniai ir detekcijos metodai, nagrinejjama literatūra, aprašanti vaisto poveikị kardiovaskulinei, nervų, endokrinologinei sistemoms. Literatūros apžvalgai naudoti 2016-2021 m. straipsniai. Remiantis atlikta apžvalga, pastebeta, kad meldoniumas turi teigiamą poveikị kardiovaskulinei ir nervų sistemoms; ilgalaikis šio vaisto vartojimas susijęs su antidiabetiniu efektu; meldoniumas mažina uždegiminių ir su tromboze susijusių žymenų koncentraciją COVID-19 infekcija sergančių pacientu kraujyje.

\section{Ivadas}

Meldoniumas (farmacinis vaisto pavadinimas - mildronatas) - tai vaistas, mažinantis 1-karnitino koncentraciją kraujo plazmoje ir audiniuose. Dèl metabolizmą moduliuojančio poveikio ši veiklioji medžiaga ịrašyta ị dopingui priklausančių medžiagų sąrašą, Lietuvoje registruota kaip vaistas papildomam lengvo lètinio širdies nepakankamumo gydymui.
Pastaruoju metu atliekama vis daugiau tyrimų, vertinančiu meldoniumo farmakologines savybes ir pritaikomumą gydyti ivairias ligas. Šiame straipsnyje aptariamas minèto vaisto veikimo mechanizmas, farmakologiniai ypatumai, analizuojamas meldoniumo poveikis kardiologinei, neurologinei ir endokrininei sistemoms.

Tyrimo tikslas - atlikti 2016-2021 m. publikuotų mokslinių straipsnių, nagrinèjančių meldoniumo (mildronato) veikimo mechanizmą, farmakologines savybes, maistinius šaltinius, detekciją organizme ir poveikị ivvairioms organų sistemoms, analizę.

\section{Tyrimo objektas ir metodika}

Duomenys buvo renkami PubMed duomenų bazèje. Analizei naudoti visateksčiai straipsniai, kurių pavadinimas, santrauka ir raktažodžiai atitiko apžvalgos tikslą. Analizuotos anglų kalba skelbtos 2016-2021 m. publikacijos. Literatūros apžvalgai atrinkti 9 straipsniai.

\section{Tyrimo rezultatai}

Meldoniumo veikimo mechanizmas. Meldoniumas yra vaistas, mažinantis L-karnitino koncentraciją kraujo plazmoje ir audiniuose. Pagrindinis jo veikimo mechanizmas - L-karnitino sintezèje dalyvaujančios $\gamma$-butirobetaino hidroksilazès (angl. BBOX) konkurencinis inhibavimas bei OCTN2 baltymo nešiklio, esančio inkstuose, blokavimas [1]. Šs meldoniumo poveikis ištirtas ir žmonèms. Meldoniumas blokuoja BBOX, inhibuodamas L-karnitino sintezę. Tai mažina L-karnitino pernašą ị mitochondriją ir lètina miokardui toksiškų ilguju grandžių RR $\beta$ oksidaciją. Dèl sumažejjusios acetil-KoA koncentracijos neaktyvuojama PDK, todèl per PDC stimuliuojama aerobinè gliukozès oksidacija, išemijos paveiktoje širdyje energijos gamybai reikalaujanti mažesnių deguonies atsargų. Ilgalaikis ilgujų grandžių RR oksidacijos slopinimas didina miokardui netoksiškų trumpujų ir vidutinio ilgio grandžių RR oksidaciją peroksisomose. Mildronato L-karnitino sintezę slopinančio poveikio schema parodyta 1 paveiksle. 
Meldoniumo kardioprotekcinis efektas. Meldoniumas geriausiai žinomas kaip kardioprotekcinị poveikį turintis vaistas. Eksperimentiniai tyrimai su laboratoriniais gyvūnais parodè, kad mildronatas pasižymi antiaterosklerotiniu, vazoprotekciniu ir antiišeminiu poveikiu širdžiai [1,2]. Minètas efektas siejamas su šiais mechanizmais: meldoniumas mažina L-karnitino koncentraciją, aktyvindamas gliukozès oksidacijos procesus ir slopindamas širdžiai toksiškų ilgụjų grandžių riebalų rūgščių oksidaciją; slopina žarnyno mikroflorą, mažindamas širdžiai kenksmingo TMAO junginio susidarymą ir didindamas jo ekskreciją per inkstus; blokuoja L-karnitino sintezę, didindamas vazoprotekcinị efektą turinčio $\gamma$-butirobetaino (GBB) koncentraciją kraujyje; aktyvina sarkoplazminio tinklo $\mathrm{Ca}^{2+-}$ ATPazès ekspresiją, palaikydamas normalią $\mathrm{Ca}^{2+}$ koncentraciją išemizuotoje širdyje [1]. Dragana Savic ir kt. eksperimentiniame tyrime trijų savaičių gydymas meldoniumu buvo siejamas su RPR rodiklio (angl. rate pressure product - išvestinis rodiklis, gaunamas širdies susitraukimų dažnị per minutę padauginus iš sistolinio arterinio kraujospūdžio) padidèjimu išemijos-reperfuzijos pažeidimo paveiktose cukriniu diabetu sergančių ir nesergančių žiurkių širdyse [3]. Teigiama širdies funkcijos dinamika buvo siejama su h-MRT tyrime užfiksuotu piruvato dehidrogenazès, gliukozès oksidacijoje dalyvaujančio fermento, suaktyvejjimu, todèl tikètina, kad meldoniumas širdies veiklą gerina blokuodamas L-karnitino sintezę. Žinoma ir keletas su žmonemis atliktų meldoniumo efektyvumo vertinimo tyrimų, kurie rodo šio vaisto silpną teigiamą poveikị širdies funkcinių rodiklių ir fizinio krūvio tolerancijos padidejimui pacientams su lètine koronarine patologija ir staziniu širdies nepakankamumu [2]. $2020 \mathrm{~m}$. atliktoje studijoje, tyrusioje meldoniumo poveiki pacientams, sergantiems lètiniu širdies nepakankamumu ir COVID-19 infekcija, komplikuota plaučių uždegimu, pastebèta, kad meldoniumas $(0,5 \mathrm{~g} / 5 \mathrm{ml}$ injekcinio tirpalo po $1 \mathrm{~g}$ per parą i veną hospitalizavimo laikotarpiu) statistiškai reikšmingai sumažino pacientų uždegiminių (CRB) ir trombozès žymenų (d-dimerų) koncentraciją kraujyje; vaisto vartojimas buvo susijęs su sutrumpejusia hospitalizacijos trukme, lyginant su kontroline grupe, kuriai buvo taikytas tik standartinis gydymas. Ivvertinus trečią mènesị po hospitalizacijos pacientams pateiktų klausimynų rezultatus, pastebèta, kad papildomas meldoniumo skyrimas (500 mg 2 kartus 2 savaites po hospitalizacijos) pagerino pacientų gyvenimo kokybę, klinikinę būklę, padidino pasitenkinimą sveikatos būkle, sumažino astenijos sunkumą [4].

Meldoniumo neuroprotekcinis poveikis. Daugejjant duomenų apie meldoniumo efektyvumą gydant kardiovaskulinius susirgimus, kyla susidomejjimas galimu šio vaisto neuroprotekciniu poveikiu. Neseniai Dilan Demir ir kt. atliktas eksperimentinis tyrimas parodè, kad meldoniumo skyrimas žiurkèms su trauminiu smegenų pažeidimu buvo susijęs su mažesniu mieloperoksidazès, kaspazès-3 aktyvumu, mažesne luminolio ir liucigenino koncentracija bei didesniu superoksido dismutazès aktyvumu smegenų audinyje, lyginant su kontroline grupe [5]. Eksperimente tiriamosioms žiurkèms nebuvo atliekami funkciniai ar elgesio vertinimo testai, todèl nebuvo galima stebèti klinikinio šio vaisto poveikio, tačiau gauti laboratorinių rodiklių rezultatai rodo, jog meldoniumas slopina uždegimą, apoptozę ir oksidacinị stresą, tad galimai turi apsauginị poveikị trauminio smegenų pažeidimo pakenktam nerviniam audiniui. Kadangi žinoma, jog skausminių sindromų, įskaitant kompleksinị regioninị skausmo sindromą (KRSS) ir periferinę neuropatiją (PN), patogenezè susijusi su mikrovaskulinès išemijos sukeltu

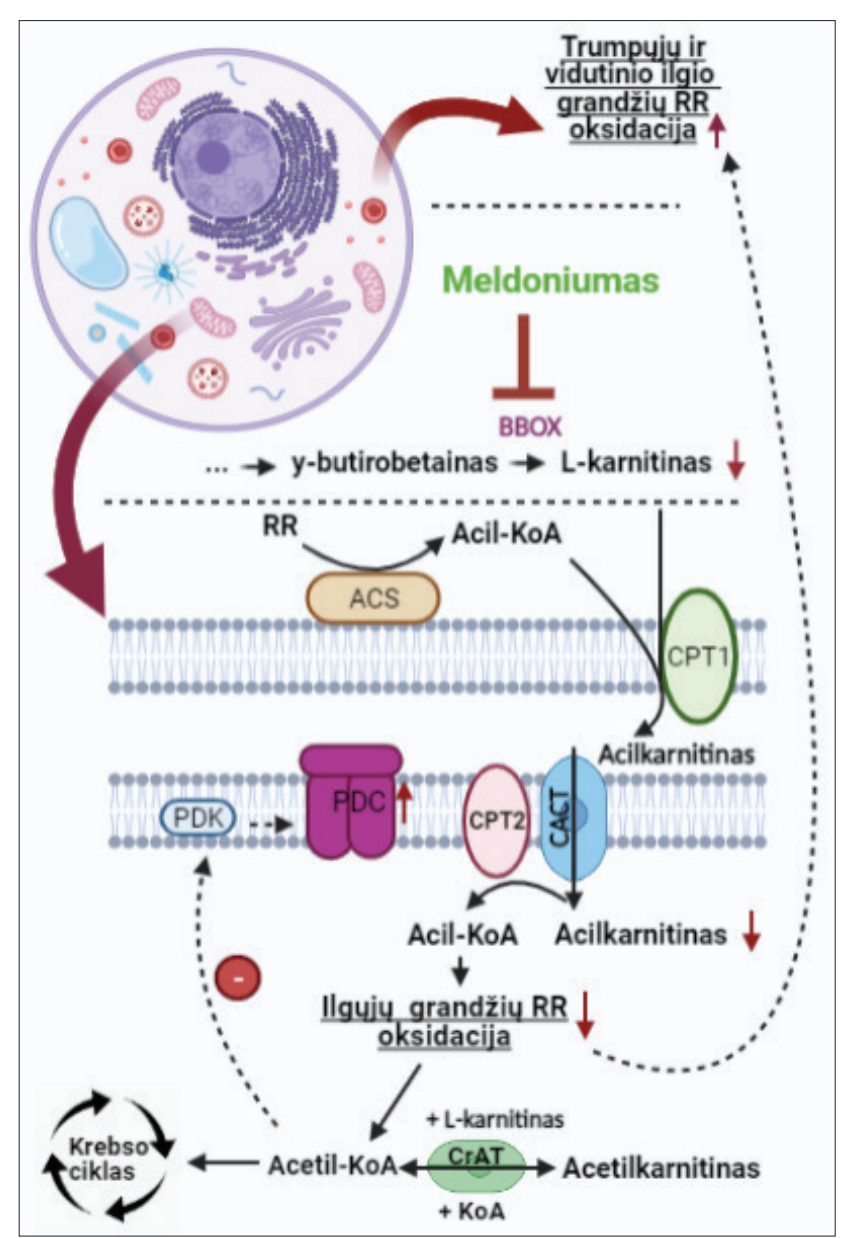

1 pav. L-karnitino sintezę slopinantis meldoniumo poveikis ACS - acil-KoA sintetazé; $\gamma$ - butirobetaino hidroksilazé; CACT - karnitino (acilkarnitino) translokazé; $C P T$ - karnitino palmitoiltransferaze; $C r A T$ - karnitino acetiltransferazé; PDC-piruvatdehidrogenazés kompleksas; $P D K$ - piruvatdehidrogenazès kinazé; $R R$ - riebalu rügštys. 
neuronų pažeidimu, manoma, kad NO sintezę aktyvinančiu poveikiu pasižymintis meldoniumas gali slopinti KRSS ir PN sukeltą skausmą. Oli A. Fulas ir kt. eksperimentiniame tyrime gydymas meldoniumu ir $\mathrm{N}$-acetilcisteinu sumažino poišemini (šis poveikis stebetas ir skyrus monoterapiją meldoniumu), nervo suspaudimo ir chemoterapijos indukuotą skausmą tiriamosioms žiurkėms, o pakartotinis šios vaistų kombinacijos skyrimas prailgino antialodininị poveikị lètinio poišeminio ir nervo suspaudimo skausmo atveju [6]. Tyrime taip pat pastebetas poišeminio skausmo sumažejimas, kai kartu su neefektyvia meldoniumo ir $\mathrm{N}$-acetilcisteino doze buvo skirta $30 \mathrm{~min}$. hiperbarinè deguonies terapija. Šiuo metu yra duomenų ir apie meldoniumo naudą ūmaus smegenų išemijos ir neurodegeneracinių ligų, įskaitant Parkinsono ligą, gydymui [2].

Meldoniumas cukrinio diabeto gydymui. Pastaruoju metu manoma, kad vienas iš rezistentiškumo insulinui vystymosi mechanizmų yra padidẻjusi ilguju grandžių acetilkarnitinų koncentracija, kurią netiesiogiai mažina meldoniumas. Eksperimentiniai tyrimai su laboratoriniais gyvūnais rodo, kad trumpalaikis mildronato skyrimas neturi įtakos gliukozès koncentracijos kraujyje pokyčiams, tačiau ilgalaikis (4 sav. ar daugiau) vaisto vartojimas didesnemis nei kardioprotekcinès dozėmis siejamas su priklausomu nuo dozès gliukozès koncentracijos sumažèjimu [1]. Remiantis tyrimais, meldoniumas ir glikemiją mažinantis vaistas metforminas turi sinergistini poveikį, didindami kepenų jautrumą insulinui. Šių vaistų kombinacija mažina svorio augimą. Kadangi meldoniumas aktyvina gliukozès oksidacijos procesus ir tokiu būdu slopina laktato kaupimąsi organizme, jis taip gali mažinti metformino sukeliamos laktatacidozès riziką, todèl galimai aptartų vaistų kombinacija ateityje galètų tapti tinkama cukrinio diabeto gydymo alternatyva.

Meldoniumas dopingo kontekste. $2016 \mathrm{~m}$. sausio $1 \mathrm{~d}$. meldoniumas pasaulinès dopingo agentūros įrašytas ị draudžiamaji sąrašą kaip metabolizmą moduliuojanti veiklioji medžiaga. Manoma, kad šis vaistas didina sportininkų fizini pajëgumą, netiesioginiu būdu skatindamas kraujagyslių išsiplètimą bei aktyvindamas gliukozès oksidacijos procesus, energijos gamybai reikalaujančius mažesnių deguonies atsargų nei riebalų rūgščių oksidacija [1]. Priešingai negu didžioji dalis ị draudžiamajji dopingo sąrašą ịtrauktų medžiagų, meldoniumas pasižymi dideliu poliariškumu, todèl ịprastiniai dopingo patikros metodai, įskaitant kietosios fazès ekstrahavimą (angl. solid-phase extraction, SPE) ar ekstrahavimą tirpikliais ir skaidymą (angl. liquid-liquid extraction), kartu su skysčių chromatografija-masès spektrometrija (angl. liquid chromatography-mass spectrometry) nèra pritaikyti šio vaisto detekcijai drauge su kitomis veikliosiomis medžiagomis. Naujausi tyrimai rodo, kad su dilute-and-shoot procedūra susijęs SPE kartu su skysčių chromatografijaaukštos skiriamosios gebos masių spektrometrija (angl. liquid chromatography-high resolution mass spectrometry, LC-HRMS) vienu metu leidžia tiksliai identifikuoti šlapime esančias skirtingomis fizikinemis ir cheminėmis savybėmis pasižyminčias medžiagas, tarp jų ir mildronatą [7]. Meldoniumas, kaip antiišeminį ir lengvą sedacinị poveikị turintis vaistas, plačiai vartojamas ir gyvulininkystès ūkiuose. A. Temerdashev ir kt. atliktas tyrimas parodė, kad ši veiklioji medžiaga linkusi akumuliuotis Emidonol preparatais gydytų karvių piene, viščiukų mėsoje ir kepenyse [8]. Ištirta, jog meldoniumo pèdsakai karvès piene gali būti aptinkami ir praejus kelioms dienoms po paskutinès $10 \mathrm{~d}$. trukmès (6 d. kasdienès injekcijos, po kurių 4 d. negydoma) gydymo kurso dienos, kartu icvertinta, kad terminis pieno apdorojimas meldoniumo koncentraciją sumažina tik iki dviejų kartų. Remiantis šiais rezultatais bei duomenimis apie tai, kad ilgalaikis gydymas meldoniumu žmogaus organizme susijęs su pailgejusia vaisto pusine eliminacija (po vienos dozès vaisto pusinès eliminacijos greitis $3-7 \mathrm{~h}$, tačiau ilgalaikis vaisto vartojimas siejamas su pusinès eliminacijos pailgèjimu iki 15 h) [2,9], galima daryti išvadą, kad minètų gyvūninès kilmès maisto produktų vartojimas gali didinti profesionaliu sportininkų diskvalifikacijos riziką.

\section{Išvados}

1. Pagrindinis meldoniumo veikimo mechanizmas susijęs su L-karnitino koncentracijos audiniuose ir kraujo plazmoje mažinimu.

2. Meldoniumui būdingas kardio- ir neuroprotekcinis, antidiabetinis ir uždegimo slopinamasis poveikis.

\section{Literatūra}

1. Dambrova M, Makrecka-Kuka M, Vilskersts R, Makarova E, Kuka J, Liepinsh E. Pharmacological effects of meldonium: biochemical mechanisms and biomarkers of cardiometabolic activity. Pharmacological Research 2016;113(Pt B):771-80.

https://doi.org/10.1016/j.phrs.2016.01.019

2. Greenblatt HK, Greenblatt DJ. Meldonium (mildronate): a performance-enhancing drug? Clinical Pharmacology In Drug Development 2016;5(3):167-69.

https://doi.org/10.1002/cpdd.264

3. Savic D, Ball V, Holzner L, Hauton D, Timm KN, Curtis MK, Heather LC, Tyler DJ. Hyperpolarized magnetic resonance shows that the anti-ischemic drug meldonium leads to increased flux through pyruvate dehydrogenase in vivo resulting in improved post-ischemic function in the diabetic heart. NMR in Biomedicine 2021;34(4):e4471.

https://doi.org/10.1002/nbm.4471

4. Верткин АЛ, Шишкова ВН, Сычева АС, Кебина АЛ, Носова 
$\mathrm{AB}$, Урянская КА, Газикова ХМ, Завьяло ГВ. Возможности метаболической поддержки при коронавирусной инфекции. Терапия 2020;7:146-155.

https://doi.org/10.18565/therapy.2020.7.146-155

5. Demir D, Bektaşoğlu PK, Koyuncuoğlu T, Kandemir C, Akakın D, Yüksel M, Çelikoğlu E, Yeğen BÇ, Gürer B. Neuroprotective effects of mildronate in a rat model of traumatic brain injury. Injury 2019;50(10):1586-1592.

https://doi.org/10.1016/j.injury.2019.08.036

6. Fulas OA, Laferriere A, Stein RS, Bohle DS, Coderre TJ. Topical combination of meldonium and n-acetyl cysteine relieves allodynia in rat models of CRPS- 1 and peripheral neuropathic pain by enhancing no-mediated tissue oxygenation. Journal of Neurochemistry 2020;152(5):570-84.

https://doi.org/10.1111/jnc. 14943

7. Oliveira D, de Araújo A, Ribeiro W, Silva D, Duarte AC, de Sousa V, Pereira HG. Screening method of mildronate and over 300 doping agents by reversed-phase liquid chromatography-high resolution mass spectrometry. Journal of Pharmaceutical and Biomedical Analysis 2021;195: 113870. https://doi.org/10.1016/j.jpba.2020.113870

8. Temerdashev A, Azaryan A, Dmitrieva E. Meldonium determination in milk and meat through UHPLC-HRMS. Heliyon 2020;6(8):e04771. https://doi.org/10.1016/j.heliyon.2020.e04771

9. Liepinsh E, Dambrova M. The unusual pharmacokinetics of meldonium: implications for doping. Pharmacological Research 2016;111:100.

https://doi.org/10.1016/j.phrs.2016.05.029

\section{MELDONIUM IN THE TREATMENT OF CARDIOVASCULAR, NEUROLOGICAL DISEASES AND DIABETES MELLITUS}

Š. Maksvytytė, P. Šerpytis

Keywords: meldonium, mechanism of action, pharmacologic properties, doping, cardioprotection, COVID-19, neuroprotection, diabetes mellitus.

Summary

Meldonium (trade name Mildronate) is an active substance that lowers 1-carnitine concentrations in blood plasma as well as in tissues thus showing the effects of metabolic modulator. Due to its performance-enhancing activity meldonium is added to the World-Antidoping-Agency (WADA) Prohibited list. Currently the only registered indication of this drug in Lithuania is a supplementary treatment of chronic cardiac insufficiency. These days little is known about pharmacologic properties and potential therapeutic effects of mildronate, thus, considering its studied characteristics, mildronate is becoming and interesting investigation field in medical sciences. In this article we will review mechanism of action, pharmacologic properties, detection methods of meldonium as well as its effects on cardiovascular, nervous, and endocrine systems. The articles from 2016 to 2020 were used for the literature review. Based on the review, it was observed that meldonium potentially has a cardio- and neuroprotective effects and that the long-term use of this drug is associated with antidiabetic effects; meldonium decreases inflammation and thrombosis-related markers in pneumonia caused by COVID- 19 .

Correspondence to: sarune25@gmail.com

Gauta 2021-04-21 